\title{
REPORT OF AN OUTBREAK OF STINGS CAUSED BY Olindias sambaquiensis MULLER, 1861 (CNIDARIA: HYDROZOA) IN SOUTHERN BRAZIL
}

\author{
Charrid Resgalla Junior*, André L. Rosseto and Vidal Haddad Jr.
}

Universidade do Vale do Itajaí - UNIVALI CTTMar-UNIVALI

(Caixa Postal 360, 88302-202 Itajaí, SC, Brasil)

*Corresponding author: cresgalla@univali.br

Descriptors: Jellyfish, Oceanographyc conditions, Winds, Water temperature, Stings identification. Descritores: Gelationosos, Condições oceanográficas, Ventos, Temperatura da água, Identificação de queimaduras.

\section{INTRODUCTION}

Accidents caused by cnidaria are common in Brazil, a country with an extensive coastline that is the site of intense leisure activity (HADDAD JR., 2000). Although there have been few papers published on this problem, some patterns have been observed for this type of sting, and the majority of cases reported in the Southeast and South regions of Brazil have been caused by Hydromedusae Olindias sambaquiensis, giving rise to injuries of moderate severity in the victims (HADDAD JR., 2000; HADDAD JR. et al., 2002, 2010). Other accidents observed have been associated, in smaller number, with the Portuguese Man o' War (Physalia physalis), two box jellyfish (Tamoya haplonema and Chiropsalmus quadrumanus) (HADDAD JR., 2000; HADDAD JR. et al., 2010) with systemic damage, and Scyphomedusae Linuche unguiculata with the condition known as seabather's eruption (HADDAD JR., et al. 2001).

Recently, careful observation of the skin marks left after contact with cnidarians has been valued as a key element in the identification of the species, which may make recognition of the agents associated with seasonal outbreaks possible (HADDAD JR. et al., 2010), thus helping to determine the first aid measures to be taken both for simple cases, such as using treatment with cold seawater and vinegar baths, and for more systemic problems, such as the hospitalization of the victims (HADDAD JR., 2000; HADDAD JR. et al., 2002, 2010).

This communication reports an outbreak of activity involving Olindias sambaquiensis, with a photographic record of the specimens found on the beaches, linking them to the skin marks found on bathers. It discusses the clinical aspects, and comments on possible contributory factors to the genesis of this outbreak. The outbreak took place at five beach resorts in the far south of the State of Santa Catarina, namely Rincão in the municipality of Içara, Arroio do Silva in the municipality of Arroio do Silva,
Morro dos Conventos in Araranguá, Gaivota in Balneário Gaivota and Bella Torres in Passo de Torres. The data for this study were obtained from the Içara Fire Department in the State of Santa Catarina, on the south coast of Brazil, and the images of bathers' lesions and of organisms stranded on the beach were obtained from the local media (www.engeplus.com.br), during the period January and February 2010.

The correlation between cutaneous lesions and the identification of the cnidarians responsible for the cases of poisoning was carried out by analysis of the images obtained, and compared with the standards presented by HADDAD JR. et al. (2010). Additional information on the first aid offered to the victims was supplied by the Içara Fire Department, and from the results obtained after treatment.

In an attempt to explain the occurrence of the outbreak during the period in question, oceanographic data on the temperature of the coastal water were obtained from the Physical Oceanography DAAC website (http://poet.jpl.nasa.gov), the Modis sensor and Aquac satellite being selected. The meteorological data were obtained from the website of the National Meteorology Institute (INMET www.inmet.gov.br) at the Santa Marta Grande Lighthouse station (SC).

Satellite data on temperature were analyzed, taking the average for the last seven years (2003 to 2009) and compared with data for 2010 , referring to January and February. The same treatment was applied to the air temperature data for 2009 and 2010, obtained from the Santa Marta meteorological station. For average wind speed and direction, hourly vectors were broken down into Cartesian coordinates for estimating prevailing winds, with daily and monthly data.

According to the Içara Fire Department (SC), from 1st January to 20th February 2010, 3,368 cases of jellyfish stings were reported among bathers at the five beach resorts in the far south of Santa 
Catarina (Fig. 1). In the Balneário de Rincão resort alone, in just one weekend (29 to 31 January 2010), 237 cases were reported, accounting for $29 \%$ of the total number recorded for the season.

The pattern of skin marks on the victims, as seen in the images taken during the outbreak, and also those recorded by the Fire Department, accorded with the profile reported for accidents involving Olindias sambaquiensis: short, round marks (Fig. 2), sometimes with short welt lines. None of the more than 3,300 victims recorded presented long, linear crossed marks or systemic phenomena, such as the breathing or cardiac problems which are typical of accidents involving Physalia or Cubozoans. The pain was intense, but not lasting, and the symptoms were relieved with the application of acetic acid (household vinegar). Over the entire Summer period, the Fire Department used 142 liters of vinegar to attend the victims, obtaining good results, particularly in view of the fact that about two-thirds of the victims were children (under 12 years of age). Besides the skin pattern of the lesions, the photographic records show various specimens of hydromedusa Olindias sambaquiensis in Balneário Rincão (Fig. 3). This species is characterized by four radial canals, numerous centripetal canals and numerous primary and secondary tentacles (BOUILLON, 1999).
Data obtained from the Physical Oceanography DAAC website show that for the year 2010, in the coastal region around Balneário Rincão, the water temperature was $2.22^{\circ} \mathrm{C}$ higher than the average for the last seven years for the months of January and February (Fig. 4). Similarly, a $2^{\circ} \mathrm{C}$ difference was observed in air temperature between the summers of 2009 and 2010 (Table 1). However, this region is characterized by low temperature waters from upwelling processes that occur in the region of the Cape Santa Marta Grande (HILLE et al., 2008), located to the north of the resorts (Fig. 1). These processes involve the ascent of cold, deep water to the coastal region, and are caused by the coastal morphology and action of the northerly wind, particularly the northeast winds, which are more intense during summer. For the January and February periods of 2009 and 2010, no marked differences between wind intensity and direction were observed, therefore this cannot provide an explanation for a year without outbreaks of jellyfish stings (2009) followed by a year with outbreaks (2010). At Balneário Rincão, specifically, the high incidence of bathers with stings over one particular weekend was associated with northerly winds, but these were preceded by a week of southerly winds (Fig. 5).

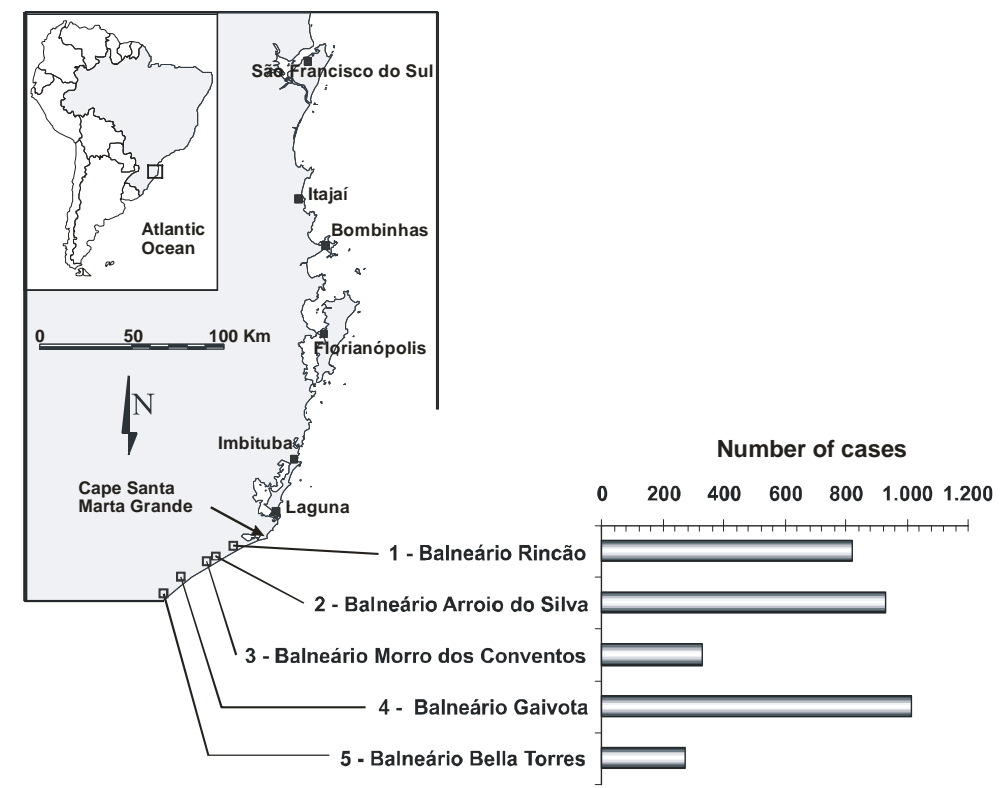

Fig. 1. Location of beach resorts and accumulated number of cases recorded by the Içara Fire Brigade, of bathers with burns caused by jellyfish from 01/01/2010 to 02/20/2010. 


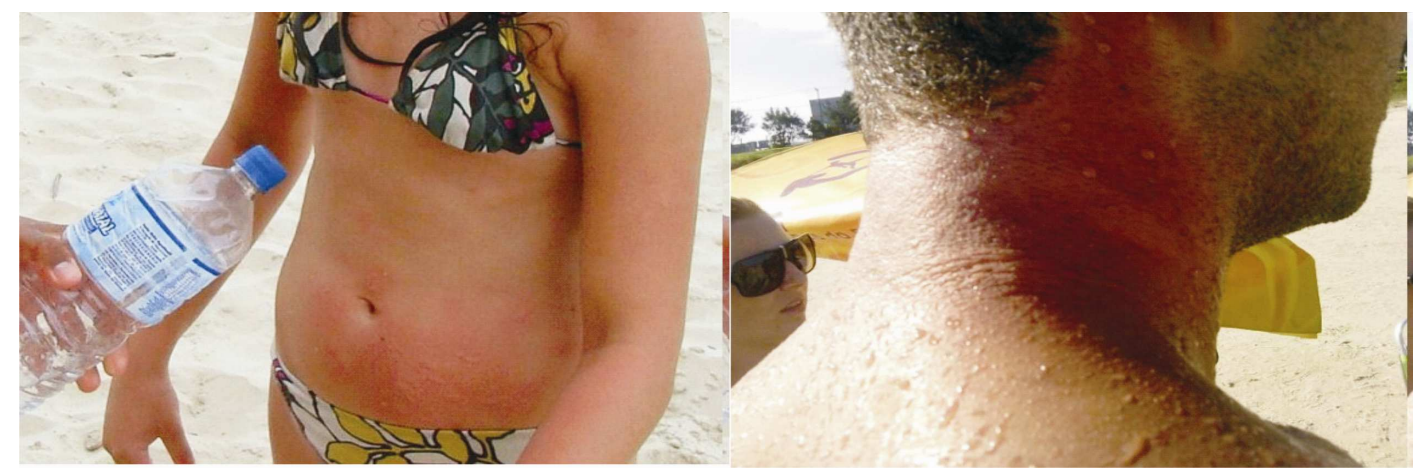

Fig. 2. Small, round lesions typical of Olindias sambaquiensis on the abdomen of a child and on the neck of an adult. Photographs taken at Balneário Rincão in January and February 2010.

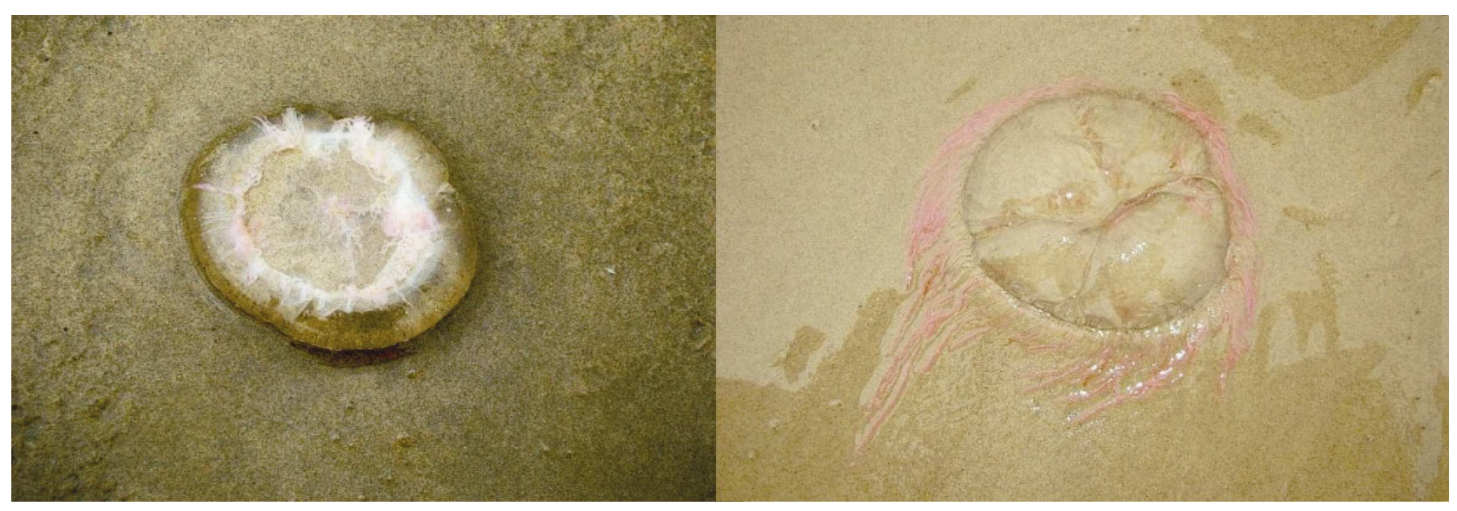

Fig. 3. Specimens of Olindias sambaquiensis occurring on Balneário Rincão beach in January and February 2010.

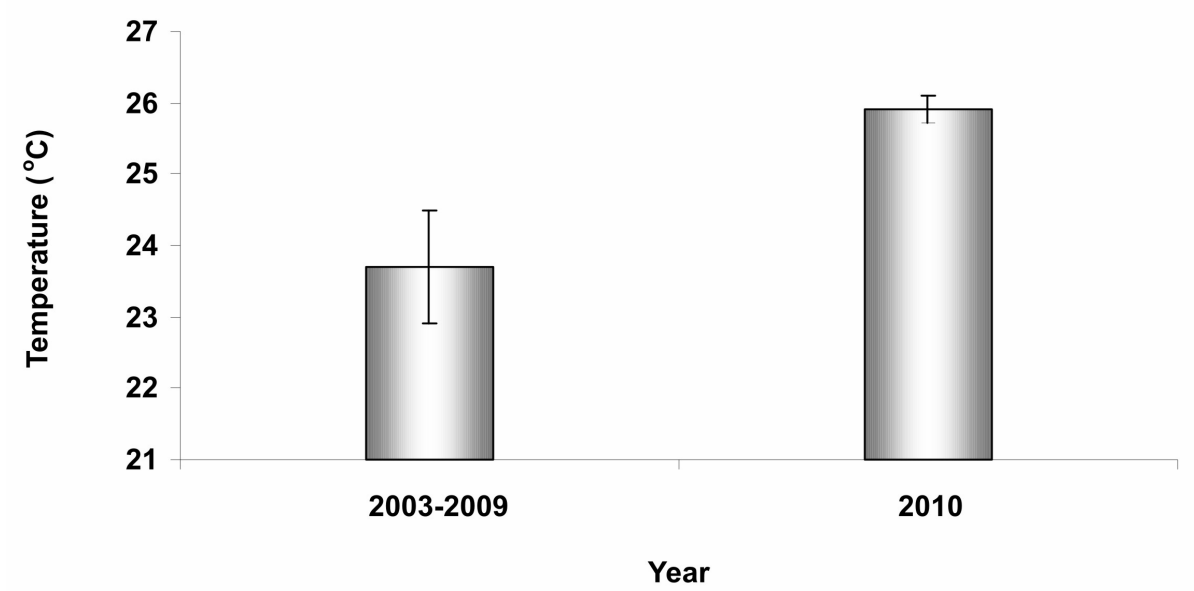

Fig. 4. Mean (column) and standard deviation (line) of the water temperature obtained by the MODIS/AQUA (Physical Oceanography DAAC) satellite for the periods 2003 to 2009 and 2010, in January and February, for the south coast of Brazil in the area around Balneário Rincão. 
Table 1 - Mean values for air temperature and wind speed and direction for January and February 2009 and 2010, obtained from the Cape of Santa Marta Grande Weather Station (INMET).

\begin{tabular}{|c|c|c|c|c|c|c|}
\hline \multirow{3}{*}{ Month/year } & \multicolumn{3}{|c|}{2009} & \multicolumn{3}{|c|}{2010} \\
\hline & \multirow{2}{*}{$\begin{array}{c}\text { Temperature } \\
{ }^{\circ} \mathrm{C}\end{array}$} & \multicolumn{2}{|c|}{ Wind } & \multirow{2}{*}{$\begin{array}{c}\text { Temperature } \\
{ }^{\circ} \mathrm{C}\end{array}$} & \multicolumn{2}{|c|}{ Wind } \\
\hline & & $\begin{array}{c}\text { Direction } \\
\text { (degree) }\end{array}$ & $\begin{array}{l}\text { Speed } \\
(\mathrm{m} / \mathrm{s})\end{array}$ & & $\begin{array}{c}\text { Direction } \\
\text { (degree) }\end{array}$ & $\begin{array}{c}\text { Speed } \\
(\mathrm{m} / \mathrm{s})\end{array}$ \\
\hline January & 22.06 & 71.33 & 2.53 & 24.04 & 45.04 & 1.82 \\
\hline February & 22.54 & 23.51 & 1.86 & 24.69 & 41.50 & 3.10 \\
\hline
\end{tabular}

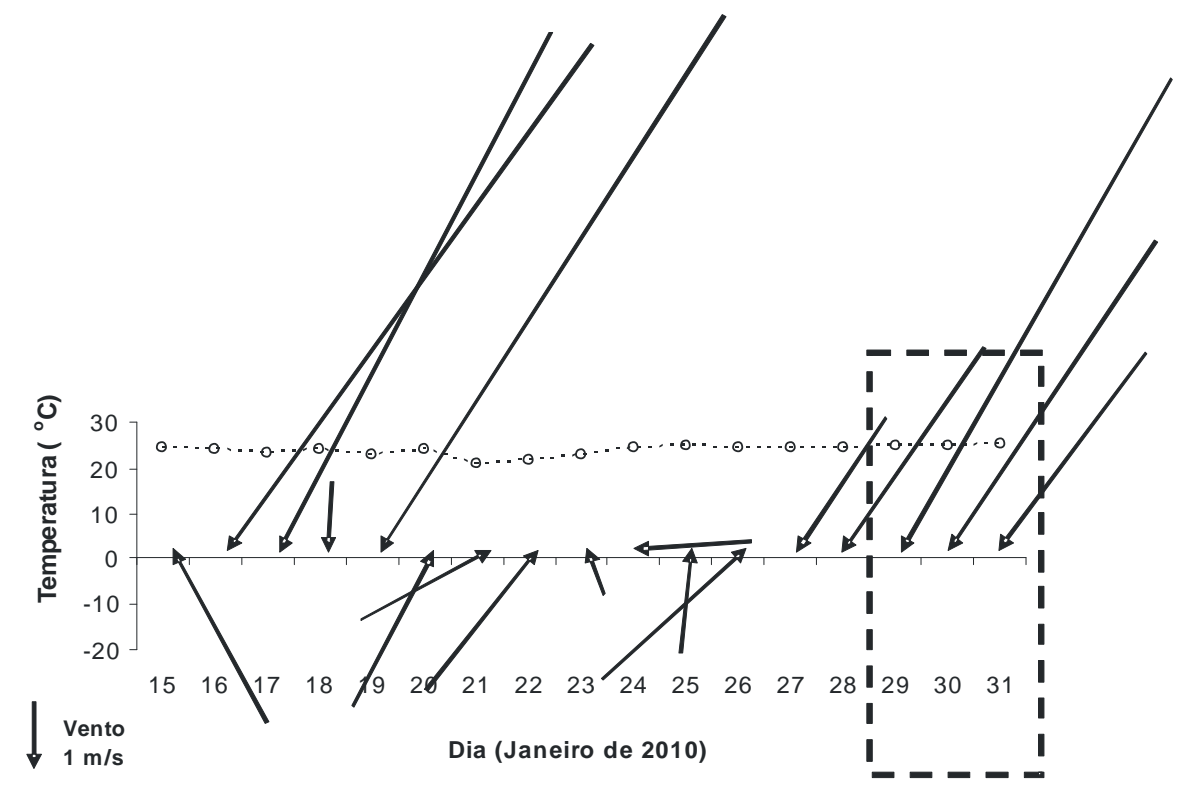

Fig. 5. Air temperature $\left({ }^{\circ} \mathrm{C}\right)$, wind speed $(\mathrm{m} / \mathrm{s})$ and wind direction at the Cape of Santa Marta Grande weather station (INMET) with daily averages for 15 to 31 January 2010. The data shown relate to the period with the highest incidence of accidents involving jellyfish at Balneário Rincão (29 to 31 January 2010) with 237 reported cases.

Nowadays, studies of mass occurrence or blooms of gelatinous organisms, particularly hydromedusae, have drawn attention because they are not only related to the productivity of the seas, but also to alterations caused by the activities of man (MILLS, 2001). Understanding these aggregations and discerning the physical processes involved in their behavior is not an easy task since it is often a combination of these two forcing elements that are responsible for these outbreaks (ARAI, 1992). When these blooms are associated with accidents involving bathers at tourist resorts, this has negative repercussions on public health and on the socioeconomic aspects of the region, prompting tourists to stay away from the area.

The etiological agent of the more than 3,300 accidents observed in the region was identified for the first time in an outbreak of stings (skin irritations) in humans in the State of Santa Catarina. The observation of the lesions and marks made it clear that the hydrozoan Olindias sambaquiensis was responsible for a large number of the injuries, which accords with the clinical profile diagnosed by Haddad Jr. (2000) and Haddad Jr. et al. (2010). The symptoms were also in accordance with those described by these same authors, and the use of vinegar as a first aid measure, applied in this case by the Fire Department, is recommended for Olindias sambaquiensis (MIANZAN et al., 2001).

$O$. sambaquiensis is endemic to the Southern Atlantic, with distribution between the Southeast region of Brazil and the North of Argentina (MIANZAN; ZAMPONI, 1988). It has frequently been mentioned as the cause of stings in bathers throughout its area of distribution (MIANZAN; ZAMPONI, 1988; MIANZAN; RAMÍREZ, 1996; HADDAD JR. et al., 2002; RESGALLA JR. et al., 2005). This fact has attracted attention to the species, particularly in relation to outbreaks and the negative impact on tourism in the coastal communities, with 
increasing interest in the genesis of and the processes involved in the occurrence of the outbreaks.

The wind systems observed over the south coast of the State of Santa Catarina in 2010 were no different from those of the previous year, but the air and water temperatures indicate different conditions and these may have propitiated the outbreak in the summer 2010 season. Stings in bathers caused by hydromedusae in these resorts are not rare, but the number of cases recorded in summer 2010 was atypical, according to the Içara fire Department. Compared to the same period in 2009 , when only sporadic cases were recorded, the main meteorological difference observed concerned the air temperature (Table 1) which was $2^{\circ} \mathrm{C}$ higher in 2010 , as also happened to the water temperature, according to historical data from the MODIS/AQUA satellite images (Physical Oceanography DAAC) (Fig. 4).

It is believed that the processes of upwelling, common at this time of year, were ineffective, permitting the intrusion of cold water at greater depths, but with the formation of a thin layer of warm water on the surface and concentrating the organisms in the coastal zone. This process has already been described by MIANZAN and GUERRERO (2000) for this same region, highlighting the prevalence of hydromedusae Olindias sambaquiensis in the waters closer to the coast. This species shows a preference for warmer waters $\left(22\right.$ to $23^{\circ} \mathrm{C}$ ) and could become concentrated in this narrow column of superficial water.

The occurrence of jellyfish in the beach regions may, likewise, be associated with winds from the South quadrant, which would probably promote their close proximity to the coast, as observed by RESGALLA JR. et al. (2005) for the north coast of Santa Catarina. Coincidentally, the period of higher incidence among bathers at Balneário Rincão was preceded by southerly winds at the end of January 2010 (Fig. 5).

In any case, there is another factor that might determine the occurrence of an outbreak of $O$. sambaquiensis stings in the south of Santa Catarina, namely the behavior, or at least the presence of a high concentration of potential victims in the resorts. The high air and water temperatures recorded are also factors that prompt the tourists themselves to visit the coastal region (RESGALLA JR. et al., 2005).

\section{ACKNOWLEDGMENTS}

The authors thank the Fire Department of the South in the person of Captain Alexandre Vieira, and the journalist Nei Manique (Portal Engeplus) for the information and images kindly granted. As also the CNPq (National Council of Scientific and
Technological Development) for the research grant, awarded through process 302165/2008-8.

\section{REFERENCES}

ARAI, M. N. Active and passive factors affecting aggregations of Hydromedusae: a review. In: BOUILLON, J.; BOERO, F.; CICOGNA, F.; GILI, J.M.; HUGHES, G. (Ed.). Aspects of Hydrozoa biology. Scientia Mar., v. 56, n. 2-3:, p. 99-108, 1992.

BOUILLON, J. Hydromedusae. In: BOLTOVSKOY, D. (Ed.). South Atlantic zooplankton. v. 1. Leiden: Backhuys Publ., 1999. P. 385-465.

HADDAD JR., V. Atlas de animais aquáticos perigosos do Brasil: guia médico de identificação e tratamento. São Paulo: Editora Roca, 2000.

HADDAD JR., V.; CARDOSO, J. L. C.; SILVEIRA, F. L. S. Seabathers eruption: report of five cases in the Southeast Region of Brazil. Rev. Inst. Med. Trop. São Paulo, v.43, n. 3, p. 171-172, 2001.

HADDAD JR., V.; SILVEIRA, F.L.; CARDOSO, J.L.C.; MORANDINI, A.C. A report of 49 cases of cnidarian envenoming from southeastern Brazilian coastal waters. Toxicon, v. 40, n. 10, p. 1445-1450, 2002.

HADDAD JR., V.; SILVEIRA, F. L.; MIGOTTO, A. E. Skin lesions in envenoming by cnidarians (portuguese manof-war and jellyfish): etiology and severity of accidents on the brazilian coast. Rev. Inst. Med. Trop. São Paulo, v. 52, n. 1:, p. 7-50, 2010.

HILLE, E.; SCHETTINI, A. C. F.; RIBEIRO, M. R. Estrutura termohalina no litoral de Santa Catarina nos anos de 2005 e 2006. In: BRAGA, E.S. (Ed.). Oceanografia e mudanças globais. São Paulo: Edusp, 2008. P. 371-381.

ODDONE, M. C.; VELASCO, G. Relationship between liver weight, body size and reproductive activity in Atlantoraja cyclophora (Elasmobranchii: Rajidae: Arhynchobatinae) in oceanic waters off Rio Grande do Sul, Brazil. Neotrop. Biol. Conserv., v. 1, n. 1, p. 1216, 2006.

MIANZAN, H. W.; GUERRERO, R.A. Environmental patterns and biomass distribution of gelatinous macrozooplankton. Three study cases in the Southwestern Atlantic ocean. Scientia Mar. v. 64, supl. 1, p. 215-224, 2000.

MIANZAN, H. W.; RAMÍREZ, F. Olindias sambaquiensis stings in the South west Atlantic. In: WILLIAMSON, J.A.H.; FENNER, P.J.; BURNETT, J.W.; RIFKIN, J.F. (Ed.). Venomous and poisonous marine animals: a medical and biological handbook. Brisbane, Australia: University New South Wales Press, 1996. p. 206-208, 301.

MIANZAN, H. W.; ZAMPONI, M. O. Estudio bioecológico de Olindias sambaquiensis Müller, 1861 (Limnomedusae, Olindiidae) en la area de Monte Hermoso. Factores meteorológicos que influyen en su aparición. Iheringia, v. 2, p. 63-68, 1988.

MIANZAN, H. W.; FENNER, J. P.; CORNELIUS, P. F. S.; RAMÍREZ, F.C. Vinegar as a disarming agent to prevent further discharge of the nematocyst of the stinging hydromedusa Olindias sambaquiensis. Cutis, v. 68, p. 45-48, 2001. 
MILLS, C. E. 2001. Jellyfish blooms: are populations increasing globally in response to changing ocean conditions? Hydrobiologia, v. 451, p. 55-68.

RESGALLA JR. C.; SOUZA, V. G. A.; KLEIN, A. H. F. The occurrence of jellyfish stings on the Santa Catarina coast, southern Brazil. Rev. Bras. Oceanogr., v. 53, p. 183186,2005 .

(Manuscript received 10 January 2011; revised 03 March 2011; accepted 18 May 2011) 